\title{
MSI2 wt Allele
}

National Cancer Institute

\section{Source}

National Cancer Institute. MSI2 wt Allele. NCI Thesaurus. Code C91357.

Human MSI2 wild-type allele is located in the vicinity of $17 q 22$ and is approximately 423 $\mathrm{kb}$ in length. This allele, which encodes RNA-binding protein Musashi homolog 2 group, plays a role in the regulation of translation. Translocations involving the gene, including $t(7 ; 17)(p 15 ; q 23)$ with HOXA9 and $t(7 ; 17)(q 32-34 ; q 23)$ with an unknown partner, are associated with the accelerated phase of chronic myeloid leukemia accelerated phase. 